\title{
Prospects of Ecotourism Development in Ganderbal District of Jammu \& Kashmir
}

\author{
Iqbal Ahmad Bhat ${ }^{*}$ and Shyju P J ${ }^{\dagger}$
}

\section{Abstract}

Tourism is considered as an important industry in the state of Jammu and Kashmir in general and the Valley of Kashmir in particular. Though the State's economy is largely depended on agriculture and horticulture, tourism is still considered as the backbone of the economy as it generates large scale employment opportunities. The industry has generated large number of jobs; particularly it has benefitted the younger generation. Boosting the economic activities in the primary, secondary and tertiary sectors in the state, tourism has continued to play a vital role in the economy of the state.

The Valley of Kashmir witnesses a huge rush of tourists especially during peak seasons and every corner of Srinagar city is filled with high movement of tourists. The movement of tourists has largely been restricted to Golden Triangle of Kashmir i.e. Srinagar, Phalgam and Gulmarg. The Government has started earmarking other virgin destinations of Kashmir and established authorities for the development of the same, but on the ground level the scene is quite different. It is imperative to assess the carrying capacity of tourist attractions especially new and emerging destinations, in order to minimize the negative impacts of tourism. Keeping in view these considerations, the present work is an attempt to highlight the tourism potential of unexplored areas in Ganderbal District, which have immense potential for ecotourism development. The

\footnotetext{
* Research Scholar (Tourism), Dept. of History of Arts, Banaras Hindu University, Varanasi, India; iqbal.bhat41@gmail.com

† Asst. Professor (Tourism), Dept. of History of Arts, Banaras Hindu University, Varanasi, India; pjshyju91@gmail.com
} 


\begin{abstract}
present study aims to identify key determining factors that examine the scope of ecotourism potential of the selected area by analyzing the pattern of visit of tourists (profiling), examining the main purpose of visit and study of perception of visitors. Another objective of the study is to conduct a resource mapping of the study area. The study is exploratory in nature but empirical tools are also applied to highlight the potential of ecotourism in Ganderbal. Structured questionnaires have been used to collect the required information and the analysis is done by using relevant statistical tools.
\end{abstract}

Keywords: Ecotourism, Carrying capacity, Tourist perception

\title{
Introduction
}

Tourism plays an important role in the economy of developing countries like India. It is recognized as the third important industry sector in the national economy. The impacts of mass tourism have resulted in a paradigm shift which has given rise to a new concept of ecotourism. The ecotourism concept is slowly emerging as the fastest growing sector worldwide. Ecotourism has become a promising tool for the sustainable development and investment opportunities in the developing countries. It confers economic value on the conservation and protection of natural areas, and represents the potential for a sustainable development of tourism in India.

Over the years India has witnessed a steady growth in tourism. The different promotional campaigns like Incredible India have helped in attracting more overseas visitors. Twelfth five year plan also gives due attention to the development of tourism in the country while emphasizing the role of pro poor tourism. In recent years, tourist interest has been changing significantly as there is a huge demand for nature friendly tourism, among other choices. India being a large country, blessed with diverse geographical features, offers a plethora of attractions to tourists.

The concept of ecotourism has been aptly described in the simple and most concise way by the International Ecotourism Society. It defines ecotourism as 'responsible travel to natural areas that 
conserves the environment and sustains the well-being of local people' (TIES- International society for Ecotourism).

Quebec declaration (2002) identified five distinct criteria to define ecotourism which includes, nature based product, minimal impact management, environmental education, contribution to conservation and contribution to community.

The definition of TIES and criteria devised by the Quebec has been aptly used in the present work to help in creating a model for sustainable ecotourism development in the proposed study area.

Though several attractions fall in the spatial definition of Biosphere reserves, there are several scenic spots which are either not explored or unutilized. If we look into the most visited places in India (in terms of nature friendly tourism) scenic places in Kerala, Uttatrakhand, Himachal Pradesh, Goa, Karnataka, Jammu and Kashmir and North Eastern states find their presence. Jammu and Kashmir has been attracting a lot of tourists both Indian and International since post independence time. The present study focuses on the ecotourism potentials of Ganderbal District in Jammu and Kashmir.

\section{Tourism Potential of Kashmir Valley- An overview}

Kashmir valley is renowned for its scenic beauty; evergreen fields enhance its grandeur as tourist attraction. In addition to the natural beauty, several agricultural products such as fruits, saffron, nuts, herbs, and finest handicrafts like carpets, shawls and embroidery in clothes add to the interests of visitors.

The beauty of Kashmir Valley was appreciated by every ruler, but it was the Mughal Emperor Jahangir who contributed a lot in extending these attractions and converting them into more popular places. Colonialism led European nations to move over large tracks of land to settle with families and govern locally acquired assets. The northern most area of the subcontinent was discovered and inhabited by British nationals in the period between 1825 to 1840 C.E. It was under such circumstances that tourism came first to this part of the country and a convenient way to enter the valley was via Uri Gorge. Once having stepped into this area, missionary zeal 
led pioneers to undertake treks of discovery into other parts who made observations and reports prompting others to follow their route. When Shakti Samant released his film 'Kashmir Ki Kali' in 1956, which overnight brought the knowledge of the beautiful landscape and territory to the knowledge of the urban population of India, the rush was on.

In the perspective plan of tourism, Ministry of Tourism, Government of India has identified Wullar- Manasbal-Sonamarg as an important tourist circuit for ecotourism development. According to the reports of J \& K tourism, in 1988, tourist arrivals to the valley was 722000 but in 2002, 1.87 million tourist arrivals were recorded. Tourism has been playing a very important role in the valley, since the majority of its benefits is the young generation.

Table 1: Tourist Arrivals to Kashmir Valley

\begin{tabular}{|c|c|c|c|c|}
\hline Sl.No & Year & Indian & Foreign & Total \\
\hline 1 & 1955 & 48190 & 2830 & 51020 \\
\hline 2 & 1965 & 35700 & 7430 & 43130 \\
\hline 3 & 1974 & 148320 & 19300 & 167620 \\
\hline 4 & 1985 & 465600 & 38020 & 503620 \\
\hline 5 & 1995 & 320 & 8200 & 8520 \\
\hline 6 & 2005 & 585700 & 19680 & 605380 \\
\hline 7 & 2010 & 701504 & 25984 & 736488 \\
\hline 8 & 2012 & 1274674 & 37166 & 1311840 \\
\hline
\end{tabular}

Source: Directorate of Tourism Kashmir

\section{Study Area}

Among eight other newly created districts, district Ganderbal came into being in the year 2007 in the large interest of maintenance of law and order, closed supervision, and above all to ensure balanced development of the areas falling within the jurisdiction of Srinagar. 


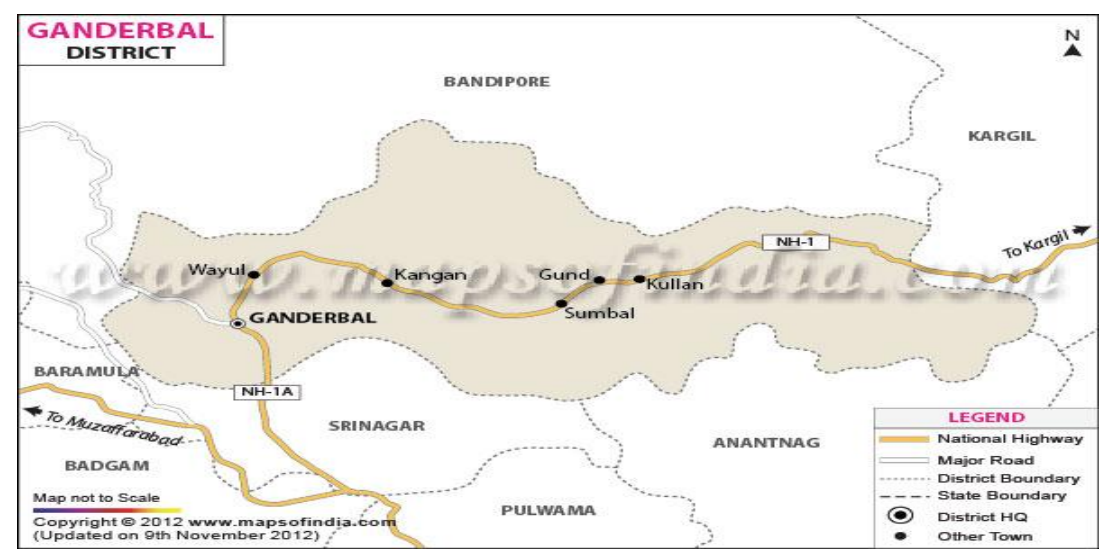

Fig. 1 : Map of Ganderbal

(Source: Maps of India)

District Ganderbal carved out of District Srinagar is flanked by District Baramulla in the west, District Srinagar in the south, District Bandipur in the North-East, Arahoma Forest in the North, and District Kargil in the East. The District is mostly spread in the north eastern direction with the length of 125 kilometres and width of about 10-20 kilometres. The administrative centre of the District is situated at Duderhama Ganderbal, which is about 15 miles away from Srinagar. Ganderbal has the distinction of having a unique geographical position as it represents the last station of the Valley of Kashmir depicting all the scenic features of the Kashmir and the gate way to the sky touching magnificent mountain ranges of the famous "Moon Land" Ladakh. The main road connecting to Ladakh region is through Sonamarg (Ganderbal) which remains closed for six months during winter due to heavy snow fall at Zojila. Added to this, the presence of the famous health resort Sonamarg and Manasbal Lake on its fringes, Qamar Sahib and Tulmulla shrines in its lap and Sindh Nallah traversing through can contribute to the emergence of this place as a recreation and pilgrim tourist spot. District Ganderbal has moderate temperature in summer and experiences severe cold in winter months like other parts of the valley. During cold weather, the district experiences plenty of snowfall from the middle of December till late February almost every year. 
The district possesses a unique topography as most of the area is hilly and covered with lush green forests. The total area under forests is 36663 hectares in the district. At present there are two forest ranges viz., Manasbal Range and Sindh Forest Division. Ganderbal has been blessed by nature with a network of water resources including River Sindh, Wangath stream, Chattergul, Markul, Tulmulla spring. Besides, high altitude lakes like Kishen Sar, Vishan Sar, Gangbal, Gad Sar, Larkul etc. In view of the topography, the district offers great potential for the development of cold water and warm water fisheries. Trout has been inhabited in the streams and lakes of district for angling purposes. Besides, the two trout rearing units' viz., Margund and Mammer have been well established in the district. In addition to it, a recreation pond has been developed at Sonamarg which is too conducive for fishing on permit basis and thus serves the purpose of entertainment. The registered fishermen in the district are about 783 who live below poverty line and derive their livelihood by exploiting the fisheries wealth from the different water bodies of the district. During the last financial year about 4057 quintals of fish have been caught from the natural water resource.

Table 2: Important Tourist Places in Ganderbal District

\begin{tabular}{|l|l|}
\hline Sl. No. & Name of the Place \\
\hline 1 & Sonamarg \\
\hline 2 & Amarnath Cave \\
\hline 3 & Gangbal \\
\hline 4 & Naranag \\
\hline 5 & Gagangir \\
\hline 6 & Prang \\
\hline 7 & Manasbal \\
\hline 8 & Kheer Bhawani \\
\hline 9 & Thajiwas Glaciers \\
\hline
\end{tabular}

\section{Literature Review}

Hector Ceballos Lascurain is a widely acknowledged person for having coined the term ecotourism. It was in 1981 that Lascurain used the term in its Spanish lingo as turisimo ecologico which was 
later on shortened to ecoturisimo. According to Ceballos Lascurain, ecotourism is a form of travel in which the natural environment is the primary focus. The centrality of the natural environment to ecotourism comprises two main facets: (i) travel to un-spoilt natural environment, (ii) the travel being primarily for experiencing the natural environment (Wearing and Neil). Ecotourism is widely recognized as a tool for community development due to its significant contribution to economy. There are four fundamental elements associated with ecotourism: travel to relatively undisturbed areas, it is nature based, it leads to conservation and lastly it has an educative role. The eco-tourist generally has an awareness of nature related issues and a desire to learn more about the environment (Galley \& Clifton, 2004). The role of ecotourism in destination development is to attract people who wish to interact with the environment and, in varying degrees, develop their knowledge, awareness, and appreciation of it.

The principles for ecotourism development laid down by International Ecotourism Society include: minimizing impacts, build cultural and environmental awareness, provide positive experiences for both visitors and hosts, direct financial benefits for conservation, financial benefits and empowerment for local people and raise sensitivity to host countries, political, environmental, and social climate (TIES,1990). According to the statistics of TIES, ecotourism currently comprises about $20 \%$ of the world travel market (TIES: ecotourism fact sheet, 2012)

Ecotourism has evolved as a popular response to the emphasis on consumerism and exploitation associated with mass tourism especially in developing countries (Buttler, 2006). The Indian chapter of the Pacific Asia Travel Association (PATA) formulated an action plan for National ecotourism policy which has been forwarded by Ministry of Tourism for the state governments for review (Boora, 2005). The outcome of this effort resulted in formulation of ecotourism policies by many states, e.g., Sikkim Ecotourism Policy envisioned establishing the state as an ultimate and unique ecotourism destination offering memorable and high quality learning experience to the visitors, while contributing towards poverty alleviation and promotion of nature conservation (Govt. of Sikkim). 
The guiding principles laid down by the Ministry of Tourism government of India for ecotourism development include: (i) local community involvement leading to overall development of the area (ii) minimize conflicts for resource use and local inhabitants (iii) ecotourism development scale should be compatible with the environment and socio-cultural characteristics of the local community (iv) it should be planned as a part of overall development strategy.

It can be said that ecotourism not only acts as an important tool for the protection of environment, but also improves the socioeconomic status of a destination. Ecotourism has the potential to be a vehicle for the enhancement of an understanding of environmental values, supportive of local communities' economies, and sense of cultural identity, as well as an activity which has arisen due to a fundamental shift in the way nature is viewed by the society.

\section{Need for the study}

The present study is an assessment of Ecotourism potential of Ganderbal District in Kashmir. The Valley of Kashmir has abundant resource base for the promotion and development of tourism in general and ecotourism in particular. Keeping this aspect into consideration the present study incorporates Ganderbal as an important ecotourism destination as it has tremendous potential for development of ecotourism. The tourism prospects of Ganderbal can be used as a promotional tool for attracting tourists from across the globe. In the perspective plan of tourism, Ministry of Tourism, Government of India has identified Wullar- ManasbalSonamarg as an important tourist circuit for ecotourism development.

Eco tourism development plan on Ganderbal district remain in abstract form and nothing has come in to effect which is either useful for tourists or benefits the local community. Lack of proper studies on identifying ecotourism destinations and designing ecotourism programmes that match with the local environment can be the main reasons for the under development of tourism in this region. The present study is an effort to explore the tourism 
potential of the selected destination, profiling visitors and examine the possible measures that can be used for tourism development in this area. There are some studies conducted on Tourism and Economy, Terrorism and Tourism, Heritage and Tourism, but except a few seminar papers nothing is available on ecotourism. On the other hand the present work is also first of its kind on the Potential and Prospects of tourism in Ganderbal District, as nothing could be found related to the same area in any of the previous studies.

\section{Objectives}

The main aim of the present work is to study the potential of ecotourism in Ganderbal District. Following are the objectives of the study:

1. To conduct the demographic profiling of visitors.

2. To analyze the purpose of visit based on tourist preference.

3. To examine the perception of visitors on ecotourism potentials of Ganderbal.

4. To identify the resources which have immense potential for ecotourism development.

\section{Scope of the study}

The study confines to the ecotourism potentials of Ganderbal District. The study is restricted to analyse the visitor's demographic pattern and their perception on the scope of ecotourism activities in the study area. Resource mapping of the area has been done in order to understand the tourism potentials of the area and a model for the sustainable development of ecotourism in Ganderbal.

\section{Research Methodology}

The study follows exploratory research methods. Both primary and secondary data have been used in the study. However, the study depends more on primary data to derive a frame work. Purposive sampling has been used to collect data from the target population 
(Tourists) and responses from 300 respondents were collected to complete the study.

\section{Sample}

The relevant data for the study has been collected mainly from primary sources. However secondary sources are used to gather the relevant information in order to comprehend the ongoing tourism scenario in the study area. Using purposive sampling procedure data was collected from the visitors to Ganderbal.

\section{Sampling instrument}

A structured questionnaire was prepared and randomly distributed during May-July 2013. The main tourist attractions and picnic spots were identified in order to distribute the questionnaires and collect data. The sample size in this study contained 300 respondents. The questionnaire was divided in to four parts, which examined the demographic profile of visitors, understand the purpose of visit and attitude of visitors on ecotourism prospects and the resource mapping of the study area

\section{Analysis}

Data collected from the respondents were analysed using SPSS 20. Multiple response analysis has been used to analyse the main purpose of visit. Factor analysis has been used to determine the key factors to analyse the attitudes of visitors and to identify main factors.

\section{Data Analysis and Discussion}

\section{Profiling}

The collection of data was done on the basis of Questionnaire distribution, interviews, postal surveys and other methods. 
Table 3 : Occupation of Respondents

\begin{tabular}{|l|c|}
\hline Occupation & Percentage \\
\hline Service & $39 \%$ \\
\hline Business & $21 \%$ \\
\hline Self Employed & $10 \%$ \\
\hline House wife & $15 \%$ \\
\hline Student & $13 \%$ \\
\hline Others & $2 \%$ \\
\hline
\end{tabular}

As per the findings of the data, $35 \%$ of tourists were foreigners and $65 \%$ were Indians with male percentage as $71 \%$ and female $29 \%$. Age wise, most of the tourists were in the age group of $>30-45$ years. Occupation wise most of the tourists were from the service sector and related fields.

Table 4 : Mode of Transport

\begin{tabular}{|l|c|c|c|c|}
\hline Category & Air & Bus & Taxi & $\begin{array}{c}\text { Others } \\
\text { (Pvt. Vehicle) }\end{array}$ \\
\hline Foreign Tourists & 57 & 20 & 23 & 0 \\
\hline Indian Tourists & 29 & 18 & 5 & 48 \\
\hline
\end{tabular}

The above table indicates that foreign tourists prefer air transport to reach the Valley, while bus and taxi are other modes to reach. Domestic tourists use private vehicle or taxis on sharing basis, some of them prefer bus services and remaining tourists prefer air services.

It is observed that $82.35 \%$ of tourists are first time visitors, $3.92 \%$ are third time visitors and $13.73 \%$ are $5^{\text {th }}$ time visitors. Fifth time visitors constitute the business and related segment.

\section{Duration of stay, age wise}

In the age group $>15$ years and up to 30 years of age, 32\% of tourists stayed in Kashmir for 3-7 days, 22\% stayed for 18-22 days and $22 \%$ for more than that time. But this may be in rare instances especially in the case of foreigners when they visit Ladakh and other such places. In general tourists spent 3-7 days on an average. 
In the age group $>30$ and up to 45 years of age, the majority of tourists $78 \%$ spent $3-7$ days. This again shows that the average stay of tourists is 3-7 days. Rest of the case may be related to some remote instances as discussed earlier.

As far the duration of stay, , majority of tourists $>45$ years of age $58 \%$ - spent 3-7 days on an average, $14 \%$ each spent 18 -22 days, 23 29 days and 30 days \& above.

Majority of tourists - 70\% - wish to revisit the valley in future. This shows the type of motivation gained from the visit to beautiful valley of Kashmir.

Table 5: Spending Pattern

\begin{tabular}{|l|c|c|c|}
\hline Spending (in Rupee) * ${ }^{*}$ per night & $\mathbf{1 5 - 3 0}$ & $\mathbf{3 1 - 4 5}$ & $\mathbf{4 6 - 6 0}$ \\
\hline 500 & 70 & 31 & 14 \\
\hline $500-1000$ & 15 & 38 & 57 \\
\hline $1000-1500$ & 15 & 16 & 29 \\
\hline $1500-2000$ & & 9 & \\
\hline Above 2000 & & 6 & \\
\hline
\end{tabular}

The above table indicates the difference of age groups on choosing their accommodation units based on cost per night basis. This table is applicable to domestic tourists only.

\section{Destinations visited}

Most of the tourists visit Srinagar $45 \%$ to see Dal Lake, Mughal Gardens, and other such places of interest. 35\% visited Gulmarg, the famous skiing resort, and $15 \%$ visit Phalgam-the valley of shepherds and only 5\% visit other destinations. This circuit is also termed as the Golden Triangle of Kashmir. 


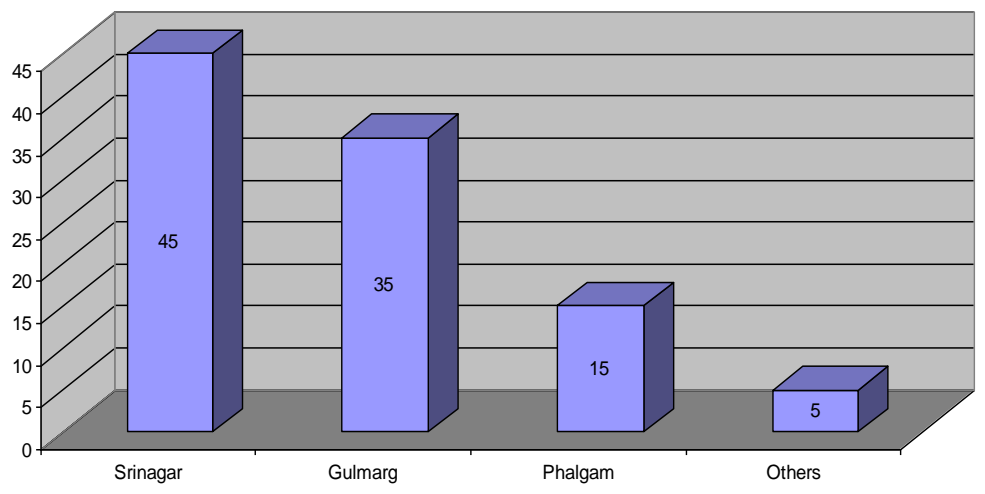

Fig.2: Destinations covered during the visit

The following graph shows that as a main tourist destination. To get Ganderbal tourist's knowledge about the attractions in the District, following data was gathered. $95 \%$ of tourists are unaware about the famous Manasbal Resort which is an upcoming destination in the district Ganderbal. 60\% know about Kheer Bhawani as it is important from the religious point of view while still $40 \%$ are unaware about it. Similarly $96 \%$ each are not aware about the famous Gangabal and Naranag Lakes which also host the ancient Hindu Temples in the form of heritage structures.

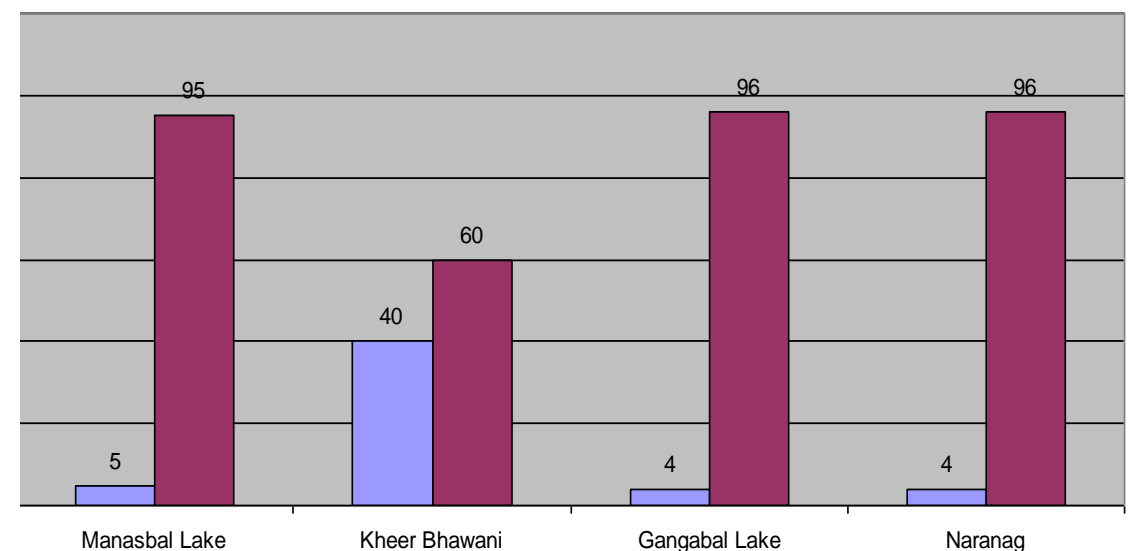

Fig.3: Knowledge about the mentioned places 
Major information sources for tourists are electronic media such as internet, as depicted in the data; $60 \%$ of the tourists used it as the information tool. Other sources include $25 \%$ as print media and $10 \%$ as friends and relatives. The study also found that majority of visitors visit valley along with family members, i.e. $45 \%$. $25 \%$ of the respondents travel in groups and a sizable share of visitors are back packers and individual visitors i.e. $20 \%$.

Table 6 : Purpose of visit

\begin{tabular}{|c|c|c|c|c|}
\hline & \multirow[t]{2}{*}{ Purpose of visit } & \multicolumn{2}{|c|}{ Responses } & \multirow{2}{*}{$\begin{array}{l}\text { Percent of } \\
\text { Cases }\end{array}$} \\
\hline & & $\mathrm{N}$ & Percent & \\
\hline \multirow{9}{*}{ 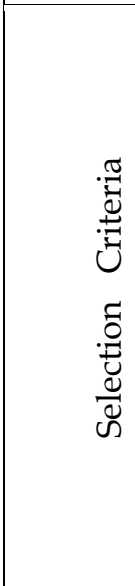 } & adventure activities & 40 & $13.3 \%$ & $40.0 \%$ \\
\hline & $\begin{array}{l}\text { pilgrimage and } \\
\text { religion }\end{array}$ & 68 & $22.7 \%$ & $68.0 \%$ \\
\hline & Shopping & 34 & $11.3 \%$ & $34.0 \%$ \\
\hline & Handicraft & 31 & $10.3 \%$ & $31.0 \%$ \\
\hline & forest and wild life & 13 & $4.3 \%$ & $13.0 \%$ \\
\hline & scenic beauty & 54 & $18.0 \%$ & $54.0 \%$ \\
\hline & other activities & 18 & $6.0 \%$ & $18.0 \%$ \\
\hline & $\begin{array}{l}\text { local culture and } \\
\text { traditions }\end{array}$ & 24 & $8.0 \%$ & $24.0 \%$ \\
\hline & Business & 18 & $6.0 \%$ & $18.0 \%$ \\
\hline \multicolumn{2}{|l|}{ Total } & 300 & $100.0 \%$ & $300.0 \%$ \\
\hline
\end{tabular}

The above table indicates that pilgrimage and religion are chosen as the highest choice as the purpose of the visit followed by scenic beauty and adventure activities. The calculated Chi-Square value is $99.852(\mathrm{P}<0.05)$ with degree of freedom 16, which shows a significant difference between the responses of different age groups and the purpose of visit. 
(ii) Analysis of opinion of visitors

Table 7 : Visitors' opinion on Tourism Prospects of Ganderbal

\begin{tabular}{|c|l|c|c|}
\hline S1.No & \multicolumn{1}{|c|}{ Statements } & Mean & $\begin{array}{c}\text { Standard } \\
\text { Deviation }\end{array}$ \\
\hline 1 & $\begin{array}{l}\text { J\&K possesses tremendous potential in } \\
\text { terms of Ecotourism }\end{array}$ & 4.07 & 1.01 \\
\hline 2 & $\begin{array}{l}\text { Ecotourism is an activity of movement } \\
\text { of people from congested to unspoiled } \\
\text { destinations like Ganderbal }\end{array}$ & 4.47 & 0.72 \\
\hline 3 & $\begin{array}{l}\text { There is a positive role of Government } \\
\text { in attracting tourists towards Manasbal } \\
\text { resort }\end{array}$ & 4.25 & 0.96 \\
\hline 4 & $\begin{array}{l}\text { There is an involvement of } \\
\text { stakeholders in framing the } \\
\text { destinations }\end{array}$ & 4.40 & 0.71 \\
\hline 5 & $\begin{array}{l}\text { Possessing natural resources helps us } \\
\text { to develop Ecotourism }\end{array}$ & 4.51 & 0.64 \\
\hline 6 & $\begin{array}{l}\text { Involvement of skilled human resource } \\
\text { helps to develop the Ecotourism }\end{array}$ & 4.46 & 0.68 \\
\hline 7 & $\begin{array}{l}\text { Ganderbal possesses tremendous scope } \\
\text { of wild life tourism }\end{array}$ & 4.14 & 1.04 \\
\hline 8 & $\begin{array}{l}\text { Serenity of Manasbal lake \& meadows } \\
\text { of snow attract tourists }\end{array}$ & 4.00 & 1.00 \\
\hline 9 & $\begin{array}{l}\text { Ganderbal should be on Ecotourism } \\
\text { map }\end{array}$ & 4.12 & 0.86 \\
\hline 10 & $\begin{array}{l}\text { There is need for developing } \\
\text { Ganderbal as an Ecotourism } \\
\text { destination }\end{array}$ & 4.14 & 0.85 \\
\hline 11 & $\begin{array}{l}\text { There is proper infrastructure in terms } \\
\text { of road connectivity at these } \\
\text { destinations }\end{array}$ & 4.51 & 0.60 \\
\hline & \multicolumn{1}{|c|}{\begin{tabular}{l} 
\\
\hline
\end{tabular}} & & \\
\hline
\end{tabular}

The above table indicates the opinion of visitors on a five point Likert Scale. The mean value of opinions of all the statements falls in between 3.9 to 4.72 , which indicates that Ganderbal has enough potential for development of ecotourism. 
(iii) Factor Analysis

Table 8: KMO and Bartlett's Test

\begin{tabular}{|l|l|r|}
\hline Kaiser-Meyer-Olkin Measure of Sampling Adequacy. & .826 \\
\hline Bartlett's Test of Sphericity & Approx. Chi-Square & $5.208 \mathrm{E} 3$ \\
\cline { 2 - 3 } & df. & 55 \\
\cline { 2 - 3 } & Sig. & .000 \\
\hline
\end{tabular}

The KMO and Bartlett's test indicate that the measure of sampling adequacy is 0.826 , with an estimated Chi Square Value of 5.28 with degree of freedom of 55 . All the measures tested above shows that the set of variables in the study is appropriate for factor analysis (Gupta \& Gupta, 2011).

Table 9 : Total Variance Explained

\begin{tabular}{|c|c|c|c|c|c|c|c|c|c|}
\hline \multirow{2}{*}{$\begin{array}{c}\text { Com } \\
\text { pone } \\
\text { nt }\end{array}$} & \multicolumn{3}{|c|}{ Initial Eigen values } & \multicolumn{3}{|c|}{$\begin{array}{l}\text { Extraction Sums } \\
\text { of Squared Loadings }\end{array}$} & \multicolumn{3}{|c|}{$\begin{array}{l}\text { Rotation Sums } \\
\text { of Squared Loadings }\end{array}$} \\
\hline & 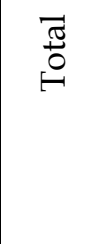 & 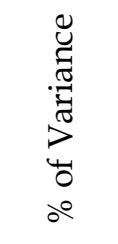 & 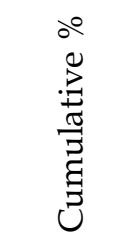 & $\stackrel{\sqrt{\pi}}{0}$ & 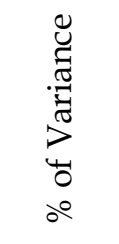 & 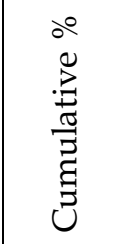 & 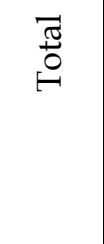 & 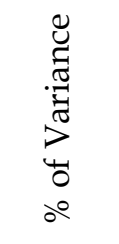 & 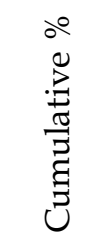 \\
\hline 1 & 7.119 & 64.721 & 64.721 & 7.119 & 64.721 & 64.721 & 4.487 & 40.792 & 40.792 \\
\hline 2 & 1.538 & 13.984 & 78.706 & 1.538 & 13.984 & 78.706 & 4.171 & 37.914 & 78.706 \\
\hline 3 & .923 & 8.395 & 87.101 & & & & & & \\
\hline 4 & .624 & 5.672 & 92.772 & & & & & & \\
\hline 5 & .269 & 2.449 & 95.221 & & & & & & \\
\hline 6 & .195 & 1.774 & 96.995 & & & & & & \\
\hline 7 & .169 & 1.539 & 98.534 & & & & & & \\
\hline 8 & .113 & 1.025 & 99.559 & & & & & & \\
\hline 9 & .022 & .203 & 99.762 & & & & & & \\
\hline 10 & .018 & .163 & 99.925 & & & & & & \\
\hline 11 & .008 & .075 & 100.000 & & & & & & \\
\hline
\end{tabular}


Observation of Eigen values explains that two major factors represent $78.70 \%$ of the variance of 11 variables in the study.

Table 10: Rotated Component Matrix

\begin{tabular}{|l|c|c|}
\hline & \multicolumn{2}{|l|}{ Component } \\
\hline & 1 & 2 \\
\hline J \& K possess tremendous potential & .790 & -.428 \\
\hline movement of people to unspoiled places & .635 & .514 \\
\hline Positive role of government & .708 & .580 \\
\hline Involvement of stake holders & .614 & .725 \\
\hline Possessing natural resources helps & .186 & .890 \\
\hline Involvement of skilled manpower & .357 & .792 \\
\hline scope of wildlife tourism & .756 & .333 \\
\hline Serenity, lake and snow & .774 & .441 \\
\hline Gandarbal should be on ecotourism map & .776 & .461 \\
\hline Need of developing Ganderbal as ecotourism spot & .780 & .490 \\
\hline there is proper road connectivity & .193 & .827 \\
\hline
\end{tabular}

The rotated component matrix suggests that the first factor is that Jammu and Kashmir possess tremendous tourism potential, ecotourism is an activity from congested places to unspoiled destinations, there is a positive role of government in attracting tourists to Manasbal, involvement of stake holders, in framing destinations, Ganderbal posses tremendous scope of wildlife tourism, serenity of Manasbal lake, meadows and snow attract tourists, Ganderbal should be on ecotourism map, need of developing Ganderbal as ecotourism destination.

The second factor is influenced by ecotourism is an activity from congested places to unspoiled destinations; there is a positive role of government in attracting tourists to Manasbal, involvement of stake holders, possessing a reliable resource helps us to develop ecotourism, involvement of skilled human resources helps us to develop the ecotourism and proper infrastructure in terms of road connectivity at these destinations.

Factor 1 is named as Ecotourism potential of Ganderbal and the second factor is named as essentials of ecotourism development. 


\section{(c) Resource Mapping}

The potential resources in Ganderbal for ecotourism development include following activities:

Table 11 : Resource Map of Ganderbal District

\begin{tabular}{|c|c|c|c|}
\hline Activity & Potential & $\begin{array}{c}\text { Opportunities } \\
\text { explored }\end{array}$ & Scope \\
\hline Ecotourism & $\begin{array}{l}\text { Scenic Beauty } \\
\text { Lakes } \\
\text { Valley } \\
\text { Hills } \\
\text { Grape Garden } \\
\end{array}$ & $\begin{array}{l}X \\
X \\
X \\
X \\
X\end{array}$ & $\begin{array}{l}\text { Immense potential to } \\
\text { explore the natural } \\
\text { beauty of the District if } \\
\text { ecotourism is } \\
\text { introduced properly }\end{array}$ \\
\hline $\begin{array}{l}\text { Soft } \\
\text { Adventure } \\
\text { Activities }\end{array}$ & $\begin{array}{l}\text { Bird } \\
\text { watching, } \\
\text { Shikara ride } \\
\text { Glacier } \\
\text { Watching, } \\
\text { Bicycle Rides } \\
\text { Forest walks }\end{array}$ & $\begin{array}{l}\sqrt{ } \\
\sqrt{ } \\
\sqrt{ } \\
x \\
x\end{array}$ & $\begin{array}{l}\text { Manasbal and adjacent } \\
\text { wetlands are famous } \\
\text { for Bird watching and } \\
\text { Shikara Ride } \\
\text { Sonamarg is } \\
\text { exclusively used for } \\
\text { glacier watching, } \\
\text { white water rafting } \\
\text { and rock climbing }\end{array}$ \\
\hline $\begin{array}{l}\text { Hard } \\
\text { Adventure }\end{array}$ & $\begin{array}{l}\text { Mountain } \\
\text { treks Rock } \\
\text { climbing } \\
\text { Mountain } \\
\text { Biking } \\
\text { Paragliding } \\
\end{array}$ & $\begin{array}{l}\sqrt{ } \\
\sqrt{ } \\
X \\
X \\
X\end{array}$ & $\begin{array}{l}\text { Sonamarg, Manasbal } \\
\text { and adjacent areas can } \\
\text { be promoted for } \\
\text { Mountain biking and } \\
\text { Paragliding }\end{array}$ \\
\hline $\begin{array}{l}\text { Cultural } \\
\text { Tourism }\end{array}$ & $\begin{array}{l}\text { Handicrafts, } \\
\text { local tradition, } \\
\text { Indigenous } \\
\text { culture }\end{array}$ & $\begin{array}{l}X \\
X \\
X\end{array}$ & $\begin{array}{l}\text { Local community can } \\
\text { be trained and } \\
\text { involved in tourism } \\
\text { activities which will } \\
\text { help them in expertise } \\
\text { in their skilled areas } \\
\text { and at the same time } \\
\text { empower them } \\
\text { economically }\end{array}$ \\
\hline
\end{tabular}

The resource base of Ganderbal is tremendous especially from the point of view of natural beauty accompanied by cultural heritage. Resource mapping helps in identifying the potential areas for 
ecotourism development. From the map it is observed that there is enough potential for ecotourism development in Ganderbal as most of the scenic spots are unexplored. Keeping in view the present scenario, Ministry of Forests and Environment Govt. of J\&K in association with Tourism Ministry introduced a new concept of eco-park at Sonamarg in order to promote ecotourism in the area. As Sonamarg is one of the developed tourist resorts of the valley and comes next after the golden triangle in the itinerary of the tourists, such a step is an added advantage for future strategy of ecotourism promotion in Ganderbal. There is requirement of similar concepts at other destinations for the promotions of ecotourism where involvement of local people to participate in such activities will help in improving their livelihood. The promotion of cultural tourism like handicrafts, local traditions and indigenous culture will help not only in gaining knowledge about such sectors but will also help in socio-economic as well as environmental preservation to a large extent.

Srinagar-Sonamarg is the existing tourist point for making an entry into the Ganderbal District. Sonamarg is known as the meadow of gold as it hosts the beautiful Thajiwas glaciers and is traditional route to Amarnath Yatra via Baltal. There are ample chances of developing a destination circuit route as proposed here:

\section{Srinagar- Kheer Bhawani- Manasbal}

Proposed activities: Craft Bazar at Tulmulla, Fruit/vegetable market at Manasbal, evening shows in open theatre at Manasbal.

\section{Srinagar-Sonamarg-Manasbal}

Proposed activities: Mini craft market exclusively of local handicrafts at Ganderbal and Kangan, participation in indigenous culture, river trail at Sindh, overnight stay and participation in cultural shows at Manasbal.

As Manasbal has been declared a tourist village and paying guest accommodation is available exclusively for foreigners, it will be an attractive product to involve the tourists in experiencing the local culture through direct participation. 


\section{Framework for ecotourism development}

The following model indicates a proposed frame work for ecotourism development in the selected study area.

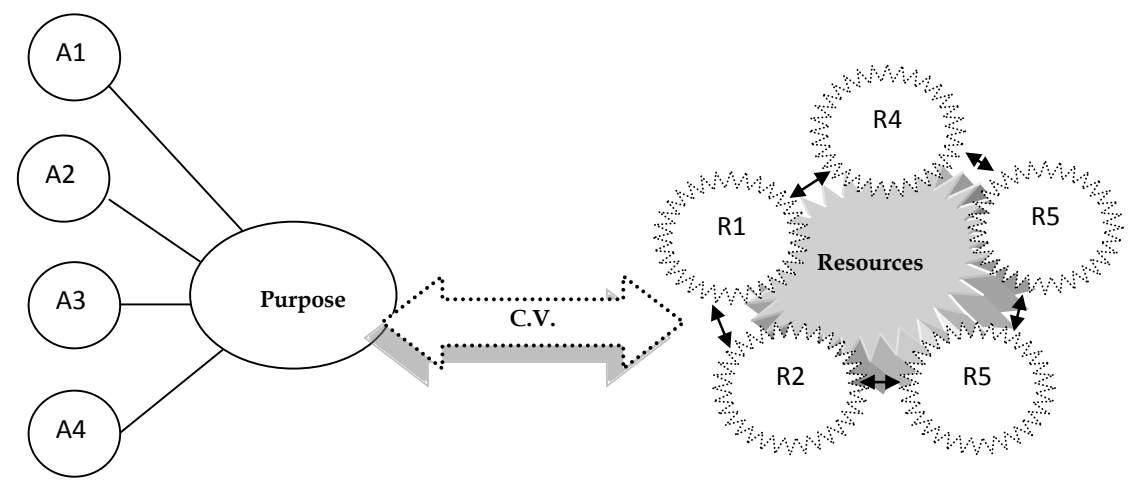

( $A=$ Activities, $C . V=$ Controlling variables, $R=$ Resources)

The above figure represents a framework for ecotourism development in Gandarbal. Tourist activities are taken from the findings of the study. These include pilgrimage and religion, scenic beauty, adventure activities, shopping, handicraft, understanding local culture etc. during their visit to valley. Although there are several attractions which have immense tourist potential, the same has not been explored much due to several factors as discussed in the introduction. The controlling variables are essentials of ecotourism development in order to explore the scope of ecotourism development in Ganderbal. Further, tourism resources of the district are highly dependent on control variables as it can lead to the development of the region through tourism. Better connectivity and exploring options for utilizing the natural resources with appropriate tourism planning in the valley can result in designing a suitable ecotourism plan for the valley. Nature based adventurous tourism activities and indigenous tourism are two major options which can be included while developing ecotourism products. An integration of these components can help in utilizing the ecotourism prospects of the region. 


\section{Conclusion}

If ecotourism practices are implemented in a proper way in the study area, it can contribute significantly to the growth and sustainability of tourism in Kashmir. Careful planning and appropriate management can play a significant role in ensuring the sustainable ecotourism ; Lindberg and Mc Kercher (1997), Ross and Wall (1999) as well as Buchs baum ( 2004). The strength of ecotourism in the proposed study area differs from other destinations as is found in the literature, such as Campbell (1999) and Weaver (1998) where ecotourism is to a large extent, used as a main economic activity, rather than being based as on an already matured industrial structure. Ecotourism contributes directly to the economy of local people when involved in the execution of policies and programs. To make ecotourism a successful example of sustainable development, local people should be involved at every level, right from planning and development. Ecotourism is a happy marriage between the traditional tourism industry and the modern concept of sustainable eco-friendly development strategy of tourism which reduces its negatives and increases the welfare of mankind. The area under study was found to be possessing tremendous potential for ecotourism as shown on the basis of factor analysis. Ganderbal possess a plethora of natural resources for successful ecotourism development. The descriptive statistics and factor analysis shows that Ganderbal District is bestowed with a nature base and ecotourism which can become a base for enhancing the same and promoting ecotourism by planned utilization of natural resources, horticultural products and involving local community.

The need of the hour is successful marketing strategies, which include a detailed appreciation of the product or products on offer, right identification of markets, use of the most efficient and effective means of communication and knowledge of the media. This shift in interest of visitors can provide a positive signal to tour operators and other service providers to reinvent their existing products or explore new destinations. 


\section{References}

Buchsbaum, B.D. (2004, May). Ecotourism and sustainable development in Costa Rica. Retrieved from http://scholar.lib.vt.edu/theses/ available/etd-05052004-171907/unrestricted/Ecotourism

CostRica.pdf

Buttler, R. (2006). Alternative tourism: pious hope or Trojan horse? Journal of travel research, 28 (3), 239-248.

Campbell, L.M. (1999). Ecotourism in rural developing communities. Annals of tourism research, 26(3), 534-553

Farid, S.A. (2003). Tourism in Kashmir. New Delhi: Rajesh Publications.

Fennel, D.A. (2002). Ecotourism. London \& New York: CABI Publishing.

Final Report of 20 Years Perspective Plan for Sustainable Development of Tourism for J E K. (2005). Retrieved from http:// tourism.gov.in/ writereaddata/CMSPagePicture/file/Primary\%20Content/MR/Ppla n/jammu\%20kashmir.pdf Boora S.S.

Galley, G., \& Clifton, J. (2004). The motivational and demographic characteristics of research ecotourists: operation Wallacea volunteers in south east Sulawesi, Indonesia. Journal of Ecotourism, 3(1), 69-82.

Gupta, S.L., \& Gupta, H. (2011). SPSS 17 for Researchers. New Delhi: International Book House.

Hussain, M. (2005). Geography of Jammu and Kashmir. New Delhi: Rajesh Publications

Incredible India. Ecotourism. Retrieved from http://www.incredibleindia.org/ travel/eco-tourism. Jammu \& Kashmir Tourism Development Corporation. Destinations. Retrieved from http://jktdc.in/destinations/srinagar.html.

Jammu \& Kashmir Tourism. Destinations. Retrieved from http:// www.jktourism.org/destinations/kashmir/sonmarg.html,

Lawrence, W.A. (2005). The Valley of Kashmir. Srinagar: Gulshan publishers.

Lindberg, K., \& McKercher, B. (1997). Ecotourism: a critical overview. Pacific Tourism Review, 1, 65-79.

National Institute of Ecology. Ecotourism and Environmental Sustainability in India Ecology(2013). Environmental Management: Issues and Research Needs in Gupta et al. Retrieved from http:/ / www.nieindia.org/ bulletin/bull-PDF/V15/B15-249.pdf

Ross, S., \& Wall, G. (1999). Ecotourism: towards congruence between theory and practice. Tourism Management, 20, 123-132.

Sikkim Biodiversity Conservation and Forest Management Project. Sikkim Ecotourism Policy. Retrieved from http:// www.ecotourismsocietyofindia.org / file/ State\% 20Policies/ Sikkim\%20Ecotourism\%20Policy.pdf. 
Wearing, S., \& Neil, J .(2009). Ecotourism: Impacts, Potentials and Possibilities. Oxford: Butterworth-Heinemann, p 5-6.

Weaver, D.B. (1998). Ecotourism in the less developed world. New York: CABI Internationals. 